\title{
'Honour Killings' in Modern Societies: A Sociological Perspective
}

\author{
Alina Zvinkliene*
}

The issues of 'honour' - and in particular honour-related crimes - in modern societies undisputedly need more public reflection and discussion, especially at the meeting points of different cultures.

The 'concept of honour and shame' - although not the only factor - is very important for understanding the background of domestic violence. This applies also - although in no way exclusively - to those Muslim family structures that are based on particular cultural traditions. The division of honour into 'true' and 'artificial' honours indicates that honour can be used to legitimate the hierarchy between members of the family. From a sociological perspective, the minimalist definition refers to honour as a right to respect. This means that honour exists both subjectively and objectively. It exists subjectively as a personal feeling as being entitled to respect. However, it exists also objectively as a public recognition of the public value of the individual. Honour/dishonour-shame always has a form of publicity.

There are two academic traditions in the interpretation of honour: honour is defined as virtue on the one hand and as dominance/hierarchy on the other. In both cases honour is considered as a value system which is gendered. Honour as virtue is usually associated with women, and honour as dominance/hierarchy links up with men. Honour is a 'cornerstone' in the construction of gender identity and public representation of masculinity-femininity in so-called 'honour and shame societies'. However, honour is not merely a gender-specific or individual genderless phenomenon; it is simultaneously a concern of the kinship group (nuclear or extended family). Therefore, honour unites the family but, simultaneously, also divides its members.

Honour expresses the group's highest values and its public recognition. Hence 'honour killing', i.e. 'washing shame with blood', of a violator of the group's values is only one method to 'restore' honour of the family in most of the 'honour and shame cultures'. The violator may be a female or a male, a member of the dishonoured family or an outsider. However, only males are allowed to 'restore' the honour of the family. In the rarest of cases, when a family does not have male members, a female may be allowed to execute the 'honour killing'.

* Prof. Dr habil. Alina Zvinkliene is Senior Research Fellow in the Department of Social Theories at the Institute for Social Research in Vilnius, Lithuania. 
Patriarchy, in its general sense, represents the institutionalisation of hierarchy. In feminist thought, patriarchy is usually defined as a system of male authority over women. The power of patriarchy is based on the greater access of men to (and mediation of) the resources and rewards of authority structures. Patriarchy is deeply embedded in culture, and, consequently, it challenges and influences the structures of social institutions responsible for 'processing' a gender identity in a boy/man and a girl/woman. The traditional Western (patriarchal, Christian) pattern of gender relations is best explored in positivist sociology and represented in the concept of the family. The family is understood as a stable nucleus with a hierarchical structure that assumes male dominance and, accordingly, the subordinate position of women and children. The husband is seen as the main breadwinner while the wife is the homemaker. Such an idea of the family implies what can be termed a 'dictatorship of marriage and childbearing'. In the West, this idea of the family was politically reformulated by the New Right ideology and strongly supported by neo-liberal policy of the governments under leadership of Margaret Thatcher in the United Kingdom and Ronald Reagan in the United States in the 1970s-80s, respectively. Hence, patriarchy affects social structures of society as gender identity. Despite the theoretical deconstruction of the concept of the family, in the Western world (and, of course, not only there) many individuals - both women and men - in their private life follow such patterns.

'Classical feminism' and/or 'post-feminism' was born and developed within the Western societies. The analysing of social theories implies the knowing that any theory is a product of a specific society and its culture. Due to the worldwide globalisation of our times, the 'local' theories may therefore have the universal keys for the explanation of 'other' societies and cultures.

The methods of control range from psychological to physical. It would be possible to speak about an egalitarian model of family relations in Islam if women would have a minimal legal prescription to the control of men at least.

In analysing cases of confirmed 'honour killings', a recent study ${ }^{1}$ distinguished the differences between the victim-perpetrator in 'honour killings' and 'ordinary' domestic violence. The victims are largely teenage daughters or young women. Wives are also victims, but to a lesser extent. Moreover, unlike most cases of Western domestic violence, 'honour killings' in a Muslim milieu are mostly carefully planned. The perpetrator's family may warn the victim repeatedly over a period of years that she will be killed if she 'dishonours' her family by refusing to veil or act as their family's domestic servant; wearing makeup or Western clothing; choosing friends from another religion; dating; seeking to obtain an advanced education; rebuffing an arranged marriage or seeking a divorce from a violent husband; or behave in ways that are considered too independent or 'westernized', 
which might mean anything from driving a car to spending time or living away from home or family.

Most importantly, only 'honour killings' involve multiple family members: fathers, mothers, brothers, male cousins, uncles, and sometimes even grandfathers commit the murder, but mothers and sisters may 'lobby' for the killing. Some mothers collaborate in the murder in a hands-on way and may assist in the getaway. Family members conducted 'honour killings' with excessive violence - repeatedly stabbing, raping, setting aflame, and bludgeoning - in more than half the cases. Only in serial-killing-type scenarios are Western women targeted with similar violence; in these cases, the perpetrators are seldom family members and their victims are often strangers. In the West, domestic violence is seldom celebrated, even by its perpetrators; wife batterers are ostracised. Here, there is an important difference in 'honour crimes'. Misguided Muslims who commit or assist in the commission of 'honour killings' often view these killings as 'heroic' and even view the murder as the fulfilment of a religious obligation. 'Honour killings' are thus not stigmatised.

According to Chesler, ${ }^{2} 90$ per cent of honour murders in the West are committed by Muslims against Muslims. The next-largest group practising honour killings is comprised of Hindus and Sikhs. Nor is there any significant difference between honour killings in North America and Europe. Neither the average age (20) nor the percentage of daughters as victims in the European cases is significantly different from those in the North American cases. In every case, perpetrators view their victims as violating rules of religious conduct and act without remorse.

Chesler's study suggests that the occurrence of 'honour killings' is accelerating in North America and may correlate with the numbers of first-generation immigrants. Immigrants who ascribe to extremist views in their religious outlook, tend to control and patrol their women very closely; a free interpretation of the rules of women's obedience may define a lot of things to kill them for. The problem is diverse but originates with immigration from majority-Muslim countries and regions - the Palestinian territories, the Kurdish regions of Turkey and Iraq, majority Muslim countries in the Balkans, Bangladesh, Egypt, Afghanistan and Pakistan. Still, there are legal interventions underway in Europe - home to between 20 and 30 million Muslim immigrants and their descendants - as opposed to perhaps 4 million in the United States and Canada. Honour-related violence is, therefore, more visible in Europe than in North America.

At the same time, neo-Orientalism reflects the Western public discourse in relation to honour in Muslim societies. The new technologies have a profound impact on it: 'honour killings' of women often feature among the news-of-the-day in the transnational media; filmed Taliban-style executions circulate on the internet and can be seen online via YouTube. Undoubtedly, the media representation of 'honour killing' is the best proof of 'washing shame' and the teaching tool for both a possible 
victim and her killer. However, thanks to the media, police, politicians, and feminist activists in Western and some of the Muslim countries are beginning to treat 'honour killings' of women as a serious social problem - and ultimately as a crime.

Despite the fact that the language of honour and shame has largely disappeared in modern Western societies, it has never really done so totally. Honour transformed into reputation, prestige or status remains a powerful motivation of an individual's behaviour in fighting for recognition of his/her public value. Notorious Western individualism does not deny the significance of the family in the life of an individual. However, 'dishonoured' families or - in the modern Western meaning - families with damaged or lost reputation, prestige or status, in an attempt to restore honour prefer a 'symbolic' rather than real killing. The violator of the family values would be 'publicly eliminated' from the family. This means that the family would compel or simply let the 'wrong' family member go away - usually with some financial support. 'Elimination' from the family is a very serious kind of punishment, especially for youngsters, because it changes their life-scenario dramatically from the start and often in a negative way. At the same time, 'symbolic killings' allow the family to 'restore honour' in their respective community and, simultaneously, to remain obedient to the state's law and, therefore, to evade the penal institutions. Moreover, 'symbolic killing' gives some chance to the violator of the family values for future forgiveness.

In the view of this writer, the issue of a 'culture of honour and shame' is thus not necessarily based on the original teachings of Islam but might well be related to certain Muslim cultural practices. 'Honour and shame cultures' are also found in countries with strong Christian traditions, such as in the Mediterranean region and Latin America. Undoubtedly, historical changes affect the perception and notion of honour and the methods to defend it. In sum, the concept of honour has shifted over time from rank and behaviour to moral character, but unfortunately the same cannot be said about everyday practice.

\section{Notes}

1. Phyllis Chesler, “Are Honor Killings Simply Domestic Violence?”, available online at http://www. phyllis-chesler.com/211/are-honor-killings-simply-domestic-violence (accessed on 14 August 2009).

2. Ibid. 